\title{
ПОГІРШЕННЯ ВІДНОСИН МІЖ США ТА КНР ПІД ЧАС СВІТОВОЇ ПАНДЕМІї COVID-19
}

Анотація: Стаття присвячена висвітленню причин погіршення відносин між США та КНР під час світової пандемії коронавірусу. Відносини між США та Китаєм завжди мали хвилеподібний характер, що пояснюється величезною амбіційністю цих гігантів і бажанням бути першим. Однак, серйозна криза між країнами відбулася під час світової боротьби з COVID-19, що викликало занепокоєння у багатьох міжнародних експертів щодо можливого початку нової холодної війни. Американський президент Дональд Трамп, звинувативщи КНР у поширенні штучного вірусу, пригрозив «розірвати усі відносини» з ним. Подальші дії обох країн спонукали до ще більш серйозного загострення у відносинах. 3 приходом до влади в США Дж.Байдена спостерігається зниження рівня напруги у двосторонніх відносинах. Новий американський президент заявив, що Білий дім готовий співпращювати з Китаєм у тому випадку, якщо це відповідає інтересам США.

Ключові слова: США, КНР, пандемія COVID-19, глобалізащія, безпековий фактор, світовий порядок

Пандемія COVID-19 змінила наш світ так, як ми навряд чи могли собі уявити. Через рік після того, як COVID-19 розпочав своє невпинне поширення по всьому світові, починають з'являтися контури глобального порядку, переробленого пандемією. Дестабілізувавши життя населення планети, вірус призвів до серйозних змін у політичній та економічній сферах країн, як всередині, так і за їх межами. Значні зміни спостерігаються й у двосторонніх і багатосторонніх відносинах між суб'єктами міжнародного права. Яскравим прикладом можуть послугувати американо-китайські відносини. Тому, в сучасних умовах є надзвичайно важливим з'ясувати розвиток двосторонніх відносини між США і Китаєм, адже це дозволяє зробити висновки про те, за яким сценарієм можуть будуватися відносини між цими державами, розглянути вплив цих «економічних гігантів» на інших акторів міжнародної арени у принципово нових умовах стрімкого розвитку процесів глобалізації та інформатизації.

Наразі ми не маємо достатньої кількості наукових робіт щодо висвітлення даної тематики, враховуючи відносну новизну даного питання. Більшість сучасних досліджень стосуються здебілышого впливу пандемії COVID-19 на світову спільноту в цілому. Тому,

\footnotetext{
•Вовчук Людмила Анатоліївна - кандидат історичних наук, доцент кафедри міжнародних відносин та зовнішньої політики Чорноморського національного університету імені Петра Могили (Миколаїв, Україна); ORCID: https://orcid.org/0000-0002-8324-5235; e-mail: luda_vovchuk@ukr.net

Бойко Аліна Олександрівна - магістр міжнародних відносин Чорноморського національного університету імені Петра Могили (Миколаїв, Україна); ORCID: https://orcid.org/0000-0002-1020-6913; e-mail: boykoalina291@ukr.net
} 
фактично, можна на пальцях перелічити наявні наукові доробки.

Серед вітчизняних дослідників варто виділити працю А. Стадніка та І. Чарських ${ }^{1}$ де автори подають аналіз зовнішньополітичних рішень країн Азійсько-Тихоокеанського регіону періоду поширення пандемії. А також статтю О.Младьонової르 де авторка, характеризуючи політику країн та їх лідерів, виділяє чотири типи поведінки цих країн щодо сучасної ситуації. Критерієм такого поділу є ставлення країн-лідерів до пандемії коронавірусу та їх рішення щодо запобігання цієї «чуми XXI століття».

у той же час більша увага щодо висвітлення даного питання спостерігається серед закордонних дослідників. Так, недоліки політики провідних країн світу на початку спалаху пандемії висвітлює у своїй роботі американський науковець Т. Крістенсен ${ }^{3}$. Автор також надає рекомендації для зниження конфліктності між країнами та їх співпраці 3 метою подолання коронавірусу.

У 2020 р. світ побачила нова праця американського дослідника Г. Кіссінджера ${ }^{4}$, в якій він зазначає, що після коронавірусу світ більше ніколи не буде таким, яким він був до того. Однак, не дивлячись на жахливі масштаби і результати цієі катастрофи, США повинні реалізовувати ключове завдання відновлення економіки країни і подальший їі розвиток, оскільки це дозволить швидше перейти країні до післякоронавірусного світового порядку.

Досить цікавою є праця гонконгського економіста та колишнього проректора Китайського університету Гонконгу Л. Цзюєна ${ }^{5}$. Автор наголошує на тому, що сьогодні відносини між Китаєм і США є найважливішими двосторонніми відносинами у світі. США та Китай є відповідно найбілышими країнами за величиною економік у світі, а також найбільшими за обсягами торговими державами у світі. Таким чином, КНР і США є найважливішими торговими партнерами одна для одної. Якщо Китай і США будуть працювати разом як партнери для досягнення спільної мети, то вони зможуть досягти успіху.

Відносини між США і Китаєм завжди мали хвилеподібний характер, що пояснюється величезною амбіційністю цих гігантів і бажанням бути першим. Чергове погіршення відносин між країнами відбулося у 2016 р., коли в ході передвиборчої кампанії президент США Дональд Трамп неодноразово критикував торгові відносини 3 Китаєм. Ставши президентом, Трамп одразу почав ініціювати розслідування щодо крадіжки інтелектуальної власності США Китаєм, а також звинувачувати китайський уряд у недобросовісному веденні торговельних відносин.

\footnotetext{
${ }^{1}$ Стаднік А.I., Чарських I.Ю. Азійсько-Тихоокеанський регіон в умовах сучасних викликів: пандемія COVID-19 // «Вісник студентського наукового товариства ДонНУ імені Василя Стуса». 2020. № 12. URL: https://jvestniksss.donnu.edu.ua/article/view/8427

${ }^{2}$ Младьонова О.Д. Тест на коронавірус: світові лідери крізь призму інформаційної політики під час пандемії COVID-19 // Вісник ХHУ Імені В.Н. Карабіна. Серія «Питання політології. 2020. №37. URL: https://periodicals.karazin.ua/politology/article/view/15962/14754

${ }^{3}$ Christensen T. A modern tragedy? COVID-19 and U.S.-CHINA relations // Brookings Institution. 2020. URL: https://www.brookings.edu/wp-content/uploads/2020/05/FP_20200507_covid_us_china_christensen_v2.pdf

${ }^{4}$ Kissinger H. The Coronavirus Pandemic Will Forever Alter the World Order // The Wall Street Journal. Opinion. 2020. URL: https://www.wsj.com/articles/the-coronavirus-pandemic-will-forever-alter-the-world-order11585953005

${ }^{5}$ Lawrence J. Lau The China - US Trade War and Future Economic Relations. Hong Kong: The Chinese University of Hong Kong, 2019. 224 p.
} 
Однак, серйозна криза між країнами відбулася під час світової боротьби з COVID-19, що викликало занепокоєння у багатьох міжнародних експертів, адже 15 травня 2019 р. президент Дональд Трамп пригрозив «розірвати усі відносини» з Китаєм через пандемію, що виникла в Ухані. Американський президент відверто назвав коронавірус винятково «китайським вірусом» і заявив, що вимагатиме компенсацію від Китаю за заподіяну шкоду. Надалі американський уряд наклав візові обмеження на китайських журналістів, що працювали у країні, зменшивши термін їх роботи до 90 днів. Зростання напруженості у відносинах між двома державами спонукало багатьох експертів говорити про ймовірність нової холодної війни

Дещо знизити рівень напруги в американсько-китайських відносинах допомогла підписана у січні 2020 р. торговельна угода, згідно з якою Китай мав здійснити структурні реформи та змінити економічний і торговий режим у сферах інтелектуальної власності, сільського господарства, фінансових послуг та валюти. Китай повинен був утримуватися від конкурентоспроможної девальвації валюти. Угода першого етапу також включала зобов'язання Китаю щодо закупівлі американських товарів і послуг у найближчі роки. Важливо те, що угода встановлювала потужну систему вирішення суперечок між країнами, шляхом оперативного й ефективного впровадження та виконання цих норм. 3 боку американської сторони, мало відбутися зниження мита на китайські товари.

Проте, у даній угоді невирішеними залишалися питання щодо кібербезпеки та китайської моделі субсидування та підтримки важливих галузей, які конкурують 3 американськими компаніями, таких як сонячна енергія та сталь. Американський бізнес почав звинувачувати КНР у «заваленні» ринків США неякісною, дешевою продукцією, яка тим самим підриває економіку та імідж країни ${ }^{7}$.

Була висловлена пропозищія, що деякі 3 цих змін будуть розглянуті під час проведення другої фази переговорів. Однак США погодились частково підтримати тарифне питання, щоб зберегти важелі впливу для наступного раунду переговорів. Д. Трамп заявив, що готовий скасувати всі тарифи, якщо обидві сторони досягнуть згоди щодо наступного етапу. Але цього не сталося.

Суперечки щодо торгівлі, прав людини та походження пандемії COVID-19 ще більше ускладнили американсько-китайські відносини. У світових 3MI все частіше з'являються звинувачення Д. Трампом китайського уряду у неправомірних діях (приховуванні уханьского вірусу), від яких потерпає увесь світ ${ }^{8}$. Не знизив рівень напруги і виступ Сі Цзіньпіня щодо незалежного перегляду глобальної реакщії на пандемію коронавірусу в рамках Всесвітньої організації охорони здоров'я, але лише після того, як вірус буде під контролем. Не допомогла і його обіцянка протягом двох років надати 2 млрд. доларів допомоги на боротьбу з COVID-19'.

\footnotetext{
${ }^{6}$ Stanly J. Analysis Are the U.S. and China entering a new Cold War? URL: https://www.thehindu.com/news/international/analysis-are-the-us-and-china-entering-a-new-cold-war/article31615458.ece ${ }^{7}$ США i Китай підписали першу частину торговельної угоди URL: https://uanews.liga.net/economics/news/ssha-i-kitay-pidpisali-pershu-chastinu-torgovelnoi-ugodi

${ }^{8}$ Donald Trump holds a news conference on the relationship with China URL: https://www.youtube.com/watch?v=kHWqHt_DWAU

${ }^{9} \mathrm{Xi}$ Jinping defends China's handling of coronavirus and backs review of global response URL: https://www.youtube.com/watch?v=20-dENpSx4I
} 
На тлі посилення пандемії коронавірусу наприкінці 2020 р. значно скоротилася економіка США, яка призвела до зростання рівня безробіття у країні ${ }^{10}$. Не менше постраждав і сам Китай. Скоротився внутрішній валовий продукт країни. Так, у першому кварталі китайський ВВП впав на 6,8\% у порівнянні $з$ аналогічним кварталом 2019 р. і на 9,9\% у порівнянні з четвертим кварталом 2019 р. ${ }^{11}$

За оцінками Bloomberg, обсяг світового ВВП у 2021 р. може впасти на 600 млрд. дол., якщо мита будуть розширені й охоплять весь американо-китайський ринок. Так, лише китайський фондовий ринок у 2018 р. через торговельну війну втратив 2,4 трлн. дол. Ця війна негативно вплинула й на акції європейських країн і самих США ${ }^{12}$.

Сучасна пандемія сприймається як США, так і КНР на національній основі, хоча як побачив світ - вірус не знає кордонів. Тому, як зазначає Генрі Кісінджер, посягання на здоров'я людей, сподіваємося, є тимчасовим явищем. У той час політичне та економічне потрясіння, яке створила пандемія, може тривати роками ${ }^{13}$. Тим самим кардинально змінюючи світовий порядок. Виходячи з цього США і КНР повинні переглянути власну політику щодо один одного аби не призвести до невідворотних наслідків.

Державний радник і міністр закордонних справ Китаю Ван Ï заявив у спільному інтерв'ю інформаційному агентству «Сіньхуа» й іншим державним 3МІ, що нещодавня політика США щодо Китаю завдала шкоди інтересам обох країн і принесла світові величезну небезпеку. Тоді ж він зазначив, що обрання Джо Байдена президентом США покращить відносини між Вашингтоном і Пекіном після чотирьох років ескалації напруженості під адміністрацією Дональда Трампа. Також він закликав США «поважати обрану Китаєм соціальну систему та шлях розвитку», додавши, що якщо Вашингтон «засвоїть уроки», конфлікти між двома сторонами можуть бути вирішені. Ван Ї зазначав про те, що Китай зробив все можливе для боротьби з поширенням вірусу, наголосивши на тому, що більшість досліджень показують, що епідемія дуже ймовірно виникла у багатьох місцях світу ${ }^{14}$.

Йозеф Брамль, експерт $з$ питань США при Німецькій раді з міжнародних відносин, заявив виданню DW, про те що пандемія Covid-19 посилила економічну та геостратегічну конкуренцію між двома світовими державами. Адже, обидві країни змагаються за контроль над торговими потоками, потоками даних, потоками фінансів, причому потоки даних є найважливішими ${ }^{15}$.

\footnotetext{
${ }^{10}$ Економіка США скорочується // Інформаційне агенство УHIAH. URL: https://www.unian.ua/economics/finance/10944869-ekonomika-ssha-skorochuyetsya-nayshvidshe-z-1946-rokucherez-pandemiyu-covid-19.html

${ }^{11}$ Экономика Китая из-за коронавируса сократилась впервые за 30 лет подсчета. URL: https://lb.ua/world/2020/04/17/455545_ekonomika_kitaya_izza_koronavirusa.html

${ }^{12} \mathrm{CШA} \mathrm{і} \mathrm{Китай} \mathrm{підписали} \mathrm{першу} \mathrm{частину} \mathrm{торговельної} \mathrm{угоди} \mathrm{URL:} \mathrm{https:/lua-}$ news.liga.net/economics/news/ssha-i-kitay-pidpisali-pershu-chastinu-torgovelnoi-ugodi

${ }^{13}$ Kissinger H. The Coronavirus Pandemic Will Forever Alter the World Order // The Wall Street Journal. Opinion. 2020. URL: https://www.wsj.com/articles/the-coronavirus-pandemic-will-forever-alter-the-world-order11585953005

${ }^{14}$ Top Chinese diplomat says relations with US at 'new crossroads' // Al Jazeera. 2020. URL: https://www.aljazeera.com/news/2021/1/2/china-senior-diplomat-says-us-relations-at-new-crossroads

${ }^{15}$ Matthias von Hein. Coronavirus pandemic further strains US-China relations // Deutsche Welle. URL: https://www.dw.com/en/coronavirus-pandemic-further-strains-us-china-relations/a-53650763
} 
Результатом цієї конкуренції стало введення США санкцій щодо китайських компаній. Так, на початку січня 2021 р. Сполучені Штати запровадили економічні санкції відносно 9 китайських компаній, серед яких і всесвітньо відомий виробник смартфонів Хiaomi. Компанії додані до так званого «чорного списку» підприємств, які працюють на військову промисловість Китаю. Також під санкції потрапив відомий авіабудівник компанія Comac. Згідно з документом адміністрації Д. Трампа компанії підпадатимуть під дію нової заборони на інвестування в США, яка змусить американських інвесторів до 11 листопада 2021 р. позбутися своїх часток у фірмах, внесених до чорного списку ${ }^{16}$.

У свою чергу, 9 січня 2021 р. уряд Китаю оприлюднив нові правила щодо покарання світових компаній за дотримання ними жорстких обмежень Вашингтона щодо ведення бізнесу з китайськими компаніями. Міністерство торгівлі Китаю заявило, що такі заходи необхідні для захисту національного суверенітету і безпеки Китаю та захисту прав китайських громадян та організацій ${ }^{17}$. Хоча китайські чиновники не згадували жодної конкретної країни, нові правила потенційно можуть втягнути світові компанії в економічну війну між Вашингтоном і Пекіном.

Такі дії КНР спровокували скасування обмеження на контакти між американськими чиновниками та їх тайванськими колегами, про що заявив державний секретар Майк Помпео ${ }^{18}$.

У той же час прем'єр міністр Австралії Кевін Рудд зазначив, що: «те, що робить Помпео, - це закладання цілої серії наземних мін для адміністрації Байдена... засолювання землі у відносинах між США та Китаєм загалом, і закладання наземних мін на Тайвані» ${ }^{19}$. Такий крок може означати кінець «єдиної політики Китаю», яка була в основі стратегічної стабільності у відносинах між країнами упродовж останніх 40 років. I на думку К. Рудд це може призвести до розірвання відносин між країнами і тим самим завдати серйозних проблем всій системі міжнародних відносин ${ }^{20}$.

МЗС КНР офіційно закликав Вашингтон припинити контакти з Тайбеем і суворо дотримуватися політики «одного Китаю». Однак у Держдепі відмовилися припинити військову допомогу Тайваню і зажадали від Пекіна зняти військовий, дипломатичний та економічний тиск на острів ${ }^{21}$. Тобто, у певній мірі Тайвань стає розмінною монетою у з'ясуванні відносин між двома світовими лідерами.

Прихід до влади у США Дж. Байдена (20.01.2021 р.) наразі не виправдав очікування

\footnotetext{
${ }^{16}$ США ввели санкції проти китайської Хiaomi // Українська правда. 2021. 14 січня. URL: https://www.pravda.com.ua/news/2021/01/14/7279969/

${ }^{17}$ Qin Amy. China's new rules could hit US firms and send a message to Biden // The Economic Times. 2021. URL: https://economictimes.indiatimes.com/news/international/business/chinas-new-rules-could-hit-us-firms-andsend-a-message-to-biden/articleshow/80206674.cms

${ }^{18}$ Pompeo says U.S. lifting 'self-imposed restrictions' on Taiwan relationship // Consumer News and Business Channel. 2021. URL: https://www.cnbc.com/2021/01/09/pompeo-says-us-lifting-self-imposed-restrictions-ontaiwan-relationship.html

${ }^{19}$ Lee Yen Nee. Pompeo is laying 'landmines' in U.S.-China relations before Biden takes office, ex-Australian leader says // Consumer News and Business Channel. 2021. URL: https:/www.cnbc.com/2021/01/11/pompeo-is-layinglandmines-in-us-china-relations-for-the-biden-administration-says-e-australian.html

${ }^{20}$ Ibidem.

${ }^{21}$ Поплавский А. По стопам Трампа: Байден ищет в Китае источник пандемии // Газета.ru. 2021. 28 января. URL: https://www.gazeta.ru/politics/2021/01/28_a_13458806.shtml
} 
Китаю щодо «нового етапу у відносинах». Хоча у самому Білому домі говорять про необхідність нового підходу у відносинах 3 Китаєм ${ }^{22}$. Під час виступу у Держдепі американський лідер заявив, що Білий дім готовий співпрацювати з Китаєм у тому випадку, якщо це відповідає інтересам США: «Ми будемо конкурувати з позиції сили, відбудовуючи нашу власну домівку на краще, працюючи з нашими союзниками та партнерами, відновлюючи нашу роль у міжнародних інститутах та повертаючи довіру до нас, та наш моральний авторитет, значну частину якого було втрачено» ${ }^{23}$.

На думку директора Інституту Далекого Сходу РАН Олексія Маслова, тиск на Китай не ослабне при Байдені, а лише придбає трохи інші контури i, можливо, іншу риторику. «Трамп робив наголос на три важливих моменти: економічні обмеження, обмеження просування китайських високих технологій в Європу і США, а також критика китайської ідеології. Якщо брати ці тези, перша може бути ослаблена при Байдені, так як це серйозно б’є по економіці США, тому що американські компанії вкрай зацікавлені в торгівлі 3 Китаєм. А ось дві інших, ймовірно, будуть тільки розвиватися. Байден продовжить вибудовувати навколо КНР антикитайський контур» ${ }^{24}$.

Тобто США підуть шляхом обмеження взаємодії з Китаєм тих країн, які хоч якось залежать, або можуть залежати від Вашингтона. у першу чергу проти КНР будуть налаштовувати Індію, крім того, буде вестися робота 3 країнами Асоціації держав Південно-Східної Азії (АСЕАН). Хоча у даному випадку «Китай зумів певною мірою спрацювати на випередження, уклавши всеосяжне торговельне партнерство 3 країнами АСЕАН, Австралією, Новою-Зеландією та Японією. Пекін хоче позиціонувати себе як геоекономічну державу, щоб врівноважити себе з США. Зіткнення між країнами якраз йтимуть за принципом витіснення або обмеження ролі Китаю у різних торгових блоках» 25 .

США спробують не дати КНР створити свій стійкий макроекономічний регіон, також буде продовжено тиск на Пекін у плані технологій з обмеженням проникнення продукції китайських компаній і різних сервісів на західні ринки. При цьому в питаннях продовження тиску на Пекін по треку пандемії, з точки зору експерта, США намагатимуться перевести вивчення витоків вірусу на розслідування без участі В003, оскільки організація не хоче використовувати цю тезу для боротьби з Китаєм ${ }^{26}$.

Так, 10 лютого 2021 р. президент США Джо Байден провів першу після вступу на посаду телефонну розмову з очільником Китаю Сі Цзіньпінем, під час якої, згідно із заявою Білого дому, він порушив питання дотримання прав людини в Китаї, торгових відносин, відносин у сфері міжнародної безпеки і боротьби зі зміною клімату. Дж. Байден наголосив, що його пріоритетами є гарантування безпеки американців, захист американського способу життя та збереження «вільного і відкритого» індо-тихоокеанського регіону.

Окрім того, Байден висловив глибоку стурбованість щодо «примусових i несправедливих» економічних методів, використовуваних Пекіном, придушення протестів

\footnotetext{
${ }^{22}$ Ibidem.

${ }^{23}$ Байден вважає Китай найбільшим конкурентом США // Українська правда. 2021. 5 лютого. URL: https://www.pravda.com.ua/news/2021/02/5/7282402/

${ }^{24}$ Поплавский А. По стопам Трампа...

${ }^{25}$ Ibidem.

${ }^{26}$ Ibidem.
} 
у Гонконгу, порушення прав людини у Синьцзяні. Водночас Президент США висловив готовність взаємодіяти з Китаєм, коли такі дії будуть в інтересах Сполучених Штатів і їхніх союзників. Двоє лідерів також обмінялися думками про боротьбу з пандемією коронавірусу, зміною клімату та розповсюдженням зброї масового ураження ${ }^{27}$.

Того ж дня американський лідер оголосив про формування спеціальної робочої групи у складі Міністерства оборони, яка повинна негайно приступити до перегляду американської військової стратегії щодо загроз з боку Пекіна. А саме підготувати свої оцінки та рекомендащії з вироблення військової стратегії щодо Китаю, технологічних питань, організаційну структуру і стратегії застосування збройних сил, а також про можливі альянси і двосторонні оборонні договори з Пекіном ${ }^{28}$.

Отже, наразі у відносинах США і Китаю настає зміна віх і вони не будуть повторенням попередньої повномасштабної конфронтації. Початок і загострення пандемії Covid-19 у світі лише стали лакмусовим папірцем у розумінні наявного стану між країнами. Американський президент Дж. Байден чітко підкреслив, що у відносинах 3 Китаєм надаватиметься перевага «граничній конкуренції». У свою чергу, уряд КНР, приймаючи такі правила гри, рухається до поставленої цілі «світового лідерства». Однак, варто розуміти, що конфронтація між цими гігантами є серйозною загрозою не лише для них, але й для всього світу.

\section{Liudmyla Vovchuk, Alina Boiko}

\section{Deterioration of relations between the United States and China during the world Covid-19 pandemic}

Abstract: The article focuses on the reasons for the deterioration of relations between the United States and China during the global coronavirus pandemic. Relations between the United States and China have always been wavy, due to the enormous ambition of these giants and the desire to be the first.

However, a serious crisis between the countries occurred during the global struggle against COVID-19, which caused concern among many international experts about the possible start of a new Cold War. US President Donald Trump, accusing China of spreading an artificial virus, threatened to «sever all relations» with him. Further actions of both countries led to an even more serious aggravation of relations.

The United States has imposed a number of tariff restrictions, imposed sanctions on Chinese companies, visa restrictions for Chinese in the United States, etc. China, in turn, has released new rules to punish global companies for adhering to Washington's strict restrictions on doing business with Chinese companies.

\footnotetext{
${ }^{27}$ Джо Байден порушив питання прав людини в Китаї у своїй першій розмові з Сі Цзіньпінем // Радіо Свобода. Новини міжнародні. 2021. 11 лютого. URL:https://www.radiosvoboda.org/a/news-baiden-kytaiperehovory/31097096.html

${ }^{28}$ Байден объявил о пересмотре американской стратегии в отношении Китая // Голос Америки. Новости. 2021. 11 февраля. URL: https://www.golosameriki.com/a/biden-announces-task-force-china/5773393.html
} 
Tightening quarantine restrictions have led to a serious economic contraction in the United States, which has led to higher unemployment and a worsening of the situation in the country as a whole. This contributed to Washington's further confrontation over Beijing.

With the coming to power of J. Biden in the United States, there has been a decrease in tensions in bilateral relations. The new US president has said that the White House is ready to cooperate with China if it is in the interests of the United States. In other words, the US-China relations are currently changing milestones and they will not be a repetition of the previous full-scale confrontation. The onset and exacerbation of the Covid-19 pandemic in the world have only become a litmus test in understanding the current situation between countries.

Keywords: USA, PRC, COVID-19 pandemic, globalization, security factor, world order 